\title{
Intergenerational Transmission of Inequality in Psychological Health"
}

\author{
Shauryaa Sharma, ${ }^{1}$ Anand Prakash ${ }^{2, *}$ \\ 1. Student, MPhil Clinical Psychology, Amity Institute of Clinical Psychology, Amity University, Rajasthan, India \\ 2. Professor \& Head, Amity Institute of Clinical Psychology, Amity University, Rajasthan, India \\ *: All corresponding should be sent to Dr. Anand Prakash. \\ 9: This work is with a commentary in the same issue. \\ Authors' Contact: Shauryaa Sharma, E-mail: shaurya.sharma10@gmail.com; Anand Prakash, E-mail: anandprakash72@gmail.com. \\ DOI: https://doi.org/10.15354/si.21.re251. \\ The authors declare no competing interest.
}

Intergenerational transmission explains the continuity in behavior and personality of individuals across generations due to genetic as well as non-genetic causes. Both determinants affect individuals and increase their susceptibility to develop psychological health problems similar to the ones experienced by their parents. Psychological health of offspring is impacted by their parents' mental illness which causing children to be unable to adequately and positively contribute to their children's healthy development. Extensive literature review depicts intergenerational transmission of various psychological conditions ranging from PTSD, depression, anxiety, conduct issues or even schizophrenia, among many others. Proposed models offering explanation of Intergenerational Transmission point towards social learning theories, attachment theories, psychodynamic theories and Integrative theories which mentions an overlap between genetic and environmental factors to explain the transmission. Intervention strategies of early detection and intervention, working with the affected parents and including family in therapy have been discussed. Working on the parent-child relationship, building resilience, promoting building up of protective factors is also mentioned as intervention techniques. Finally, some limitations and directions of future researches have been proposed.

Keywords: Intergenerational transmission; Intergenerational trauma; Mental illness; Psychological health

Science Insights, 2021 December 28; Vol. 39, No. 5, pp.379-390.

(C) 2021 Insights Publisher. All rights reserved. (c) (i) (5) Creative Commons Non Commercial CC BY-NC: This article is distributed under the terms of the Creative Commons Attribupermission provided the original work is attributed by the Insights Publisher.

\section{Introduction}

I NTERGENERATIONAL transmission delineates a continuity across generations with respect to behavior and other characteristics. This transmission across generations can be a result of genetic factors (e.g., traits are transmitted from parents to children), a result of environmental factors or due to a complex interaction of both. This transference of char- acteristics may affect the same trait across generations, or may affect various different traits (1).

Parenting patterns and styles along with parental psychopathology have an impact of the behavior and individual characteristics possessed by the offspring. These characteristics are transmitted across the generations and are so pervasive influencing a number of factors likely to be ranging from biological 
factors of health or body type, socioeconomic, cognitive (like education and consequently their academic accomplishments), and even psychological factors, e.g., personality or vulnerability to mental illnesses.

These intergenerational patterns of behavior may result in social disadvantages and also impact their health status $(2,3)$. The offspring may be at a greater risk for experiencing and developing internalizing disorders like depression or anxiety or bipolar disorders (4). They may face issues like Post Traumatic Stress Disorder $(5,6)$, childhood conduct issues (7) etc. Mental health issues subsequently affect the growth in the social status of the individual as the illness may prevent the individual from attaining social class that they could have achieved (8). Therefore this reciprocal causation ensures that the disadvantaged groups of individuals are caught up in the loop, according to Anderson (2).

The current paper draws from the various empirical, meta-analysis and review research articles written, to expand our knowledge and understanding about the Intergenerational Transmission (Table 1). Researchers conducted with respect to mental health are explored to assess the current level of knowledge and also understand the scope for future research. An extensive review of literature was conducted on intergenerational transmission of inequality in psychological health using various search engines like Google Scholar, Pubmed, Psycinfo, Researchgate, APA Psycnet etc. The keywords used in literature search were intergenerational transmission, intergenerational trauma, and intergenerational transmission in mental health, psychological issues and their intergenerational transmission, Inequality in mental health, intergenerational transmission \& inequality etc. Research papers written in English language and mostly from 2000 till the present time were included. In order to systematically analyze the data and draw meaningful inferences from it, qualitative content analysis was employed.

\section{Intergenerational Transmission of Trauma}

The intergenerational trauma increases vulnerability to mental health issues. It is referred to as 'Transgenerational Trauma' due to its characteristic of being transmitted from one generation to another (9). And it may also be addressed as 'Historic Trauma' as it may affect a number of individuals of a specific cultural group (10). The Intergenerational Trauma alludes to the cycle of transmission of trauma from parents to offsprings leading to the experiences of traumatic events by the second generation, despite not being directly exposed to the incident (11). The transmission is known to be unintentional and accidental and often without a conscious awareness of its link with the original traumatic incident (12). Research studies have shown that offsprings of individuals who survived the Holocaust during World War II and had not witnessed the atrocities of the incident firsthand but had heard the narratives of incidents of their parents, had risks to experience PTSD, troubles with interpersonal relationships \& functions, difficulty in sensing individuality and an elevated sensitivity to stressful life situations, anxiety and depression. But at the same time, they also experienced and displayed more resilience and cultural strength $(5,6)$.

This increased vulnerability is considered due to successive generations learning the behavior and thinking patterns of their parents or caregivers as the children may replicate the parents' adaptation strategies to the trauma, or the exposure to the secondary environmental and psychological effects of these adaptations (13). Trauma leads to the caregivers displaying unpredictable and inconsistent affective reaction to the offspring (14). This, in turn, leads to dissociative difficulties or mood and even behavioral symptoms in the next generation $(15,16)$. Adults may also be unable to adequately respond to their children due to the physical and psychological injuries that they have sustained after surviving the trauma and this may lead to child abuse or even neglect (17). Trauma experiences are also transmitted through the attachment styles within the family that the child has with their caregivers (14). Consequently, sustained traumatic stress, domestic violence, childhood abuse, complex trauma, or any other event or experience occur resulting in long-term effects, as evidenced by almost identical traumatic stress response activation and altered perceptions of trust, safety, worldview, and self in the next generation (15). Thus, we can say that the magnitude of the parent's trauma and the stress from the economic disadvantages they have to face make it difficult for the parents to provide a supportive, nurturing atmosphere during early years of the child's life and increase the likelihood to intergenerational transmission of adverse childhood experiences and chronic stress for the offspring (18).

Indigenous communities have also always been on the receiving end multigenerational trauma as they have gone through traumatic events in the past which have also been aggravated by years of structural inequality (19). These communities have been exposed for several years to oppression and psychological trauma in addition to repeated violation of their basic human rights, systemic discrimination and loss of their cultural heritage (10, 20). Disparity and disproportionality also exist among wellbeing and health of the indigenous and non-indigenous communities. This is a consequences of the direct social determinants related to colonization, marginalization, intergenerational trauma and inability of the governing bodies to address the inequalities existing within the health sector (21). Many of the Aboriginal communities suffered from death, slavery, being forced out of their homelands, tortured for practicing and propagating their culture, being torn away from their families and children (22). Individuals living in these communities went through genocides, underwent relocations or displaced from their homeland led them to experience what Davoine and Gaudilliere (23) described as 'frozen trauma' that existed in the past but can also be experienced in the present. Eisenbruch (24) while working with refugees gave the term 'cultural bereavement' which is defined as the experience of 'uprooted person or group resulting from loss of social structures, cultural values and self-identity' which may trigger a sense of guilt for abandoning culture and homeland.

Children within these communities are also impacted by the intergenerational transmission of trauma. It is conspicuously shown that children exposed to violence within their family experience trauma related behavior similar to children's acts of war-affected countries (25). Insana et al. (26) said that two-third of the children who have had to witness violence within the families have sleep issues, frequent nightmares and these children also show deficient adaptive functioning. Such impacts are likely to induce behavioral \& emotional problems, anxiety dis- 
Table 1. Summary of Major Studies.

\begin{tabular}{|c|c|c|c|c|}
\hline Author & Title of Paper & $\begin{array}{l}\text { Year of } \\
\text { Publication }\end{array}$ & Major findings & Limitations \\
\hline O'Neill et al. & $\begin{array}{l}\text { Hidden Burdens: a Review of } \\
\text { Intergenerational, Historical and } \\
\text { Complex Trauma, Implications } \\
\text { for Indigenous Families }\end{array}$ & 2018 & $\begin{array}{l}\text { Psycho-sociocultural effects, Intricacy \& } \\
\text { interaction between intergenerational } \\
\text { trauma, epigenetics and the influence on } \\
\text { one's culture are discussed. }\end{array}$ & $\begin{array}{l}\text { Content analysis made the } \\
\text { process tedious and time } \\
\text { consuming, lacking a theoret- } \\
\text { ical basis being a reductive } \\
\text { approach. }\end{array}$ \\
\hline Kirmeyer et al. & Rethinking Historical Trauma & 2014 & $\begin{array}{l}\text { Reflected on suffering from intergenera- } \\
\text { tional trauma, ongoing structural vio- } \\
\text { lence \& how historic trauma impacts } \\
\text { mental health of communities. }\end{array}$ & $\begin{array}{l}\text { Limited information provided } \\
\text { about the methodology fol- } \\
\text { lowed for inclusion, screening } \\
\text { and analysis of literature. }\end{array}$ \\
\hline Kim et al. & $\begin{array}{l}\text { Intergenerational Transmission } \\
\text { of Internalising and Externalis- } \\
\text { ing Behaviours Across Three } \\
\text { Generations: Gender-Specific } \\
\text { Pathways }\end{array}$ & 2009 & $\begin{array}{l}\text { Gender specific mechanism of inter- } \\
\text { generational transmission of externaliz- } \\
\text { ing and internalizing behavior. }\end{array}$ & $\begin{array}{l}\text { Mediational factors that con- } \\
\text { tribute towards poor parenting } \\
\text { skills were not considered. }\end{array}$ \\
\hline Hammen et al. & $\begin{array}{l}\text { Intergenerational Transmission } \\
\text { of Depression: Test of an Inter- } \\
\text { personal Stress Model in a } \\
\text { Community Sample }\end{array}$ & 2004 & $\begin{array}{l}\text { Interpersonal Stress Model of transmis- } \\
\text { sion of depression, maternal depression } \\
\text { to interpersonal stress, social function- } \\
\text { ing \& diagnosing depression in offspring. }\end{array}$ & $\begin{array}{l}\text { It included nonclinical mater- } \\
\text { nal samples with } \\
\text { subsyndromal symptoms \& } \\
\text { diagnosed cases of youth } \\
\text { depression. }\end{array}$ \\
\hline Jafee et al. & $\begin{array}{l}\text { Early-onset and recurrent de- } \\
\text { pression in parents increases } \\
\text { risk of intergenerational trans- } \\
\text { mission to adolescent offspring }\end{array}$ & 2020 & $\begin{array}{l}\text { Assessed increased vulnerability of } \\
\text { depression in adolescents with parents } \\
\text { diagnosed with an early onset and re- } \\
\text { current course of depressive disorders. }\end{array}$ & $\begin{array}{l}\text { Since the children were as- } \\
\text { sessed for depression at age } \\
15, \text { therefore little is known } \\
\text { about the onset and course of } \\
\text { their condition. }\end{array}$ \\
\hline O'Reilly et al. & $\begin{array}{l}\text { The intergenerational transmis- } \\
\text { sion of suicidal behavior: an } \\
\text { offspring of siblings study }\end{array}$ & 2020 & $\begin{array}{l}\text { Similarities in suicidal acts between } \\
\text { parents and offspring, impact of shared } \\
\text { genetic factors, parental behavioral } \\
\text { health problems \& environment on } \\
\text { transmission. }\end{array}$ & $\begin{array}{l}\text { Assessed such acts in children } \\
\text { before } 18 \text { years of age, no } \\
\text { further investigation on vul- } \\
\text { nerable age ranges during } \\
\text { adolescence. }\end{array}$ \\
\hline Mackenzie & $\begin{array}{l}\text { Intergenerational transmission } \\
\text { of anxiety: The influence of } \\
\text { parental anxiety on child-related } \\
\text { information processing biases }\end{array}$ & 2011 & $\begin{array}{l}\text { Focused on transmission of anxious } \\
\text { behavior in children due to parental } \\
\text { anxiety and its association with their } \\
\text { information processing biases. }\end{array}$ & $\begin{array}{l}\text { Causality could not be estab- } \\
\text { lished as the study was } \\
\text { cross-sectional and correla- } \\
\text { tional. }\end{array}$ \\
\hline D'Onofrio et al. & $\begin{array}{l}\text { Intergenerational Transmission } \\
\text { of Childhood Conduct Problems: } \\
\text { A Children of Twins Study }\end{array}$ & 2007 & $\begin{array}{l}\text { Familial transmission of conduct prob- } \\
\text { lems, environment mediating the trans- } \\
\text { mission in male offsprings \& genetic } \\
\text { issues in the female offsprings. }\end{array}$ & $\begin{array}{l}\text { Randomly drawn from the } \\
\text { community reduces chances } \\
\text { of including participants with } \\
\text { extreme conduct or antisocial } \\
\text { personality disorders. }\end{array}$ \\
\hline $\begin{array}{l}\text { Tzoumakis et } \\
\text { al. }\end{array}$ & $\begin{array}{l}\text { Female Juvenile Delinquency, } \\
\text { Motherhood, and the Intergen- } \\
\text { erational Transmission of Ag- } \\
\text { gression and Antisocial Behav- } \\
\text { ior }\end{array}$ & 2012 & $\begin{array}{l}\text { Mothers of delinquents were likely to } \\
\text { face social adversities, use substance } \\
\text { during pregnancy and offended during } \\
\text { adulthood \& also had an early onset of } \\
\text { physical aggression among their chil- } \\
\text { dren. }\end{array}$ & $\begin{array}{l}\text { Small sample size \& also a } \\
\text { lack of access to previous } \\
\text { criminal or medical records of } \\
\text { the mothers and therefore, } \\
\text { information could not be cor- } \\
\text { roborated. }\end{array}$ \\
\hline Alyott et al. & $\begin{array}{l}\text { Like father like daughter: } \\
\text { sex-specific parent-of-origin } \\
\text { effects in the transmission of } \\
\text { liability for psychotic symptoms } \\
\text { to offspring }\end{array}$ & 2018 & $\begin{array}{l}\text { Showed psychotic symptoms more } \\
\text { common in female offsprings of affected } \\
\text { fathers and male offspring of affected } \\
\text { mothers suggesting a X-chromosome } \\
\text { linked genetic transmission. }\end{array}$ & $\begin{array}{l}\text { Included an unequal ratio of } \\
\text { fathers and mothers as par- } \\
\text { ticipants with some infor- } \\
\text { mation about the diagnosis of } \\
\text { biological parents of the chil- } \\
\text { dren not being reliable. }\end{array}$ \\
\hline Kerr \& Capaldi & $\begin{array}{l}\text { Introduction to the Special Sec- } \\
\text { tion on the Intergenerational } \\
\text { Transmission of Risk for Sub- } \\
\text { stance Use }\end{array}$ & 2020 & $\begin{array}{l}\text { Parental substance use during adoles- } \\
\text { cence and its transmission in their chil- } \\
\text { dren; sheds light on prevention reducing } \\
\text { effects of intergenerational transmission. }\end{array}$ & $\begin{array}{l}\text { Offer insight on theoretical and } \\
\text { methodological advances in } \\
\text { intergenerational transmission } \\
\text { of substance use. }\end{array}$ \\
\hline Neppl et al. & $\begin{array}{l}\text { The Intergenerational Transmis- } \\
\text { sion of Harsh Parenting, Sub- } \\
\text { stance Use, and Emotional } \\
\text { Distress: Impact on the } \\
\text { Third-Generation Child }\end{array}$ & 2020 & $\begin{array}{l}\text { Parents' problems (G1) led to alcohol- } \\
\text { ism \& emotional distress in their children } \\
\text { (G2) predicted a harsh parenting style } \\
\text { by (G2) in early onset of aggression in } \\
\text { the offsprings (G3). }\end{array}$ & $\begin{array}{l}\text { The study sample had not } \\
\text { adequately representative of } \\
\text { the population and this de- } \\
\text { creased the generalizability of } \\
\text { the results. }\end{array}$ \\
\hline Higgins et al. & $\begin{array}{l}\text { Offspring of parents with chronic } \\
\text { pain: a systematic review and } \\
\text { meta-analysis of pain, health, } \\
\text { psychological, and family out- } \\
\text { comes }\end{array}$ & 2015 & $\begin{array}{l}\text { Parents with chronic pain was linked to } \\
\text { higher externalizing and internalizing } \\
\text { symptoms, decreased social compe- } \\
\text { tence and family outcomes in their chil- } \\
\text { dren. }\end{array}$ & $\begin{array}{l}\text { The given study could not } \\
\text { evaluate the quality of primary } \\
\text { researches that were included. }\end{array}$ \\
\hline Stone \& Wilson & $\begin{array}{l}\text { Transmission of risk from par- } \\
\text { ents with chronic pain to off- } \\
\text { spring: an integrative conceptual } \\
\text { model }\end{array}$ & 2016 & $\begin{array}{l}\text { Identified genetic, neurological, social } \\
\text { learning-related mechanisms responsi- } \\
\text { ble for transmitting risk of chronic pain } \\
\text { behaviour from parents to offsprings etc. }\end{array}$ & $\begin{array}{l}\text { Failed to evaluate quality of } \\
\text { primary researches included in } \\
\text { the review, but very diverse } \\
\text { studies were included. }\end{array}$ \\
\hline
\end{tabular}




\begin{tabular}{|c|c|c|c|c|}
\hline $\begin{array}{l}\text { Goodman \& } \\
\text { Gotlib }\end{array}$ & $\begin{array}{l}\text { Risk for Psychopathology in the } \\
\text { Children of Depressed Mothers: } \\
\text { A Developmental Model for } \\
\text { Understanding Mechanisms of } \\
\text { Transmission }\end{array}$ & 1999 & $\begin{array}{l}\text { Proposes an Integrative model explain- } \\
\text { ing risk factors in offsprings of mothers } \\
\text { with depression with heritability, neuro- } \\
\text { psychology, negative maternal attitudes } \\
\text { and general life stressors. }\end{array}$ & $\begin{array}{l}\text { The study displays a lack of } \\
\text { broad, in-depth investigation } \\
\text { into the genetic and environ- } \\
\text { mental causes contributed } \\
\text { towards transmission of risk. }\end{array}$ \\
\hline Kellermann & $\begin{array}{l}\text { Transmission of Holocaust } \\
\text { Trauma-An Integrative View }\end{array}$ & 2001 & $\begin{array}{l}\text { Proposes psychodynamic, sociocultural, } \\
\text { family system \& biological models on } \\
\text { transmission of trauma across genera- } \\
\text { tions. }\end{array}$ & $\begin{array}{l}\text { Fails to delve into the devel- } \\
\text { opmental history of individu- } \\
\text { als. }\end{array}$ \\
\hline Wickrama et al. & $\begin{array}{l}\text { Early Adversity and Later } \\
\text { Health: The Intergenerational } \\
\text { Transmission of Adversity } \\
\text { Through Mental Disorder and } \\
\text { Physical Illness }\end{array}$ & 2005 & $\begin{array}{l}\text { Investigated processes of transmitting } \\
\text { illnesses \& found disruptions in normal } \\
\text { development during transition to adult- } \\
\text { hood mediated intergenerational conti- } \\
\text { nuity. }\end{array}$ & $\begin{array}{l}\text { Sample for the study was not } \\
\text { adequately representative of } \\
\text { the study population. }\end{array}$ \\
\hline Boursnell & $\begin{array}{l}\text { Parents With Mental Illness: The } \\
\text { Cycle of Intergenerational Men- } \\
\text { tal Illness }\end{array}$ & 2011 & $\begin{array}{l}\text { Showed childhood trauma-caused } \\
\text { mental illness of parent's damaged } \\
\text { effective parenting. But, did well in } \\
\text { breaking the transmission of mental } \\
\text { illness \& abuse when offered interven- } \\
\text { tion. }\end{array}$ & $\begin{array}{l}\text { The qualitative research pat- } \\
\text { tern and a very small sample } \\
\text { size decrease generalizability } \\
\text { of the results. }\end{array}$ \\
\hline Isobel et al. & $\begin{array}{l}\text { Preventing intergenerational } \\
\text { trauma transmission : A critical } \\
\text { interpretive synthesis }\end{array}$ & 2019 & $\begin{array}{l}\text { Intergenerational transmission of trauma } \\
\text { via attachment \& offered prevention, } \\
\text { resolving parental trauma \& supporting } \\
\text { parent- child attachment for intervention. }\end{array}$ & $\begin{array}{l}\text { The systematic review used } \\
\text { the critical interpretative syn- } \\
\text { thesis (CIS) which lacks } \\
\text { transparency in data analysis. }\end{array}$ \\
\hline Yap et al. & $\begin{array}{l}\text { Modifiable parenting factors } \\
\text { associated with adolescent } \\
\text { alcohol misuse: A systematic } \\
\text { review and meta-analysis of } \\
\text { longitudinal studies }\end{array}$ & 2017 & $\begin{array}{l}\text { Identified factors of risks, protection and } \\
\text { a range of modifiable parental factors } \\
\text { associated with alcohol use/ misuse by } \\
\text { their adolescents. }\end{array}$ & $\begin{array}{l}\text { The meta-analysis could not } \\
\text { be free from researcher's bias } \\
\text { regarding the inclusion or } \\
\text { exclusion of the literatures for } \\
\text { being selected. }\end{array}$ \\
\hline $\begin{array}{l}\text { Woods-Jaeger } \\
\text { et al. }\end{array}$ & $\begin{array}{l}\text { Promoting Resilience: Breaking } \\
\text { the Intergenerational Cycle of } \\
\text { Adverse Childhood Experiences }\end{array}$ & 2018 & $\begin{array}{l}\text { Influence of adverse childhood experi- } \\
\text { ence on parents, their parenting styles, } \\
\text { and some protective factors of interven- } \\
\text { tion strategies. }\end{array}$ & $\begin{array}{l}\text { Very small sample size, and } \\
\text { data through interview de- } \\
\text { creased generalizability of the } \\
\text { results. }\end{array}$ \\
\hline Hatch et al. & $\begin{array}{l}\text { Family Social Support Buffers } \\
\text { the Intergenerational Associa- } \\
\text { tion of Maternal Adverse Child- } \\
\text { hood Experiences and Pre- } \\
\text { schoolers' Externalizing Behav- } \\
\text { ior }\end{array}$ & 2020 & $\begin{array}{l}\text { Observed how maternal family social } \\
\text { support buffering adverse childhood } \\
\text { experiences of the mother and exter- } \\
\text { nalizing behavior of the child. }\end{array}$ & $\begin{array}{l}\text { Causality could not be estab- } \\
\text { lished as the study design was } \\
\text { cross-sectional. }\end{array}$ \\
\hline Branje et al. & $\begin{array}{l}\text { Intergenerational transmission: } \\
\text { Theoretical and methodological } \\
\text { issues and an introduction to } \\
\text { four Dutch cohorts }\end{array}$ & 2020 & $\begin{array}{l}\text { Cohort studies explored genetic \& other } \\
\text { factors \& psychopathologies across } \\
\text { generations. Also offer insight into the } \\
\text { methodological challenges. }\end{array}$ & $\begin{array}{l}\text { The longitudinal and cohort } \\
\text { study designs are not time- } \\
\text { and cost-effective. }\end{array}$ \\
\hline $\begin{array}{l}\text { Babcock } \\
\text { Fenerci et al. }\end{array}$ & $\begin{array}{l}\text { Intergenerational Transmission } \\
\text { of Trauma-Related Distress: } \\
\text { Maternal Betrayal Trauma, } \\
\text { Parenting Attitudes, and Be- } \\
\text { haviors }\end{array}$ & 2016 & $\begin{array}{l}\text { Described how externalizing and inter- } \\
\text { nalizing symptoms can be observed in } \\
\text { children of mothers with a history of } \\
\text { childhood abuse and betrayal trauma. }\end{array}$ & $\begin{array}{l}\text { Causality could not be estab- } \\
\text { lished as the study design was } \\
\text { cross-sectional. }\end{array}$ \\
\hline Griffith et al. & $\begin{array}{l}\text { How colonisation determines } \\
\text { social justice and Indigenous } \\
\text { health-a review of the literature }\end{array}$ & 2016 & $\begin{array}{l}\text { Colonial injustice, inequality, prejudice, } \\
\text { racism, discrimination etc in health } \\
\text { experience indigenous communities } \\
\text { through trauma. }\end{array}$ & $\begin{array}{l}\text { The publications chosen were } \\
\text { the ones only conducted in } \\
\text { Australia \& hence findings will } \\
\text { have limited generalizability. }\end{array}$ \\
\hline
\end{tabular}

orders by adulthood as well as PTSD.

\section{Intergenerational Transmission Affecting Mental Health}

While we have extensively discussed the intergenerational transmission of trauma and its consequences, a number of other psychiatric condition also have to been observed to be transmitted across generations. A number of extensive researches have been conducted to understand the transmission of various internalizing and externalizing disorders. Evidences show that internalizing disorders in the child are generally linked to maternal issues while externalizing disorders have a link with the paternal factors (27). A study by Kim et al. (28) investigated three generations across a time span of 20 years to observe the effects, transmission and gender pathways of both internalizing and externalizing behavior in parents and its effects on their offsprings. Results showed that the mother's internalizing symptoms had a strong effect on similar symptoms in the children across the three generations, irrespective of the child's gender. The father's externalizing behavior could be predicted by the grandmother's internalizing as well as externalizing behavior. Furthermore, female children's internalizing and exter- 
nalizing behavior could be predicted by their father's corresponding behavior.

A study by Hammen et al. (29) mentioned a link between Depression among mothers and their interpersonal stress affecting quality of the parenting towards their offsprings. In effect, it predicted poor social functioning, chronic interpersonal stress and depression in the children by adolescence. Jafee and others (30) reported that an early onset and recurrent course of depression among parents increased the risk of major depressive disorder in the adolescent by 4.21 times. An association has also been observed between suicidal behaviors in the parents leading to a similar behavior displayed by their children. Children of mothers who attempted or died of suicide were at 2.74 times increased risk of attempting suicide themselves (31). In addition to heritability and genetic factors $(32,33)$, close contact with parents with suicidality $(32,34)$, bereavement after death of parents $(35,36)$, negative or hostile parenting styles $(37,38)$, disorganized and chaotic home environment $(33,39)$ are observed to be the risk factors for transmission of suicidality from parents to offsprings.

Much research has also been conducted to know about the intergenerational transmission of anxiety from parents to children (40). Anxious parents, through their interaction style and behavior, influence the development of anxious information processing bias in their offspring (41). Daleiden and Vasey (42) explained the consequence of this bias as the child's increased susceptibility to be selective by focusing only on threatening stimulus in the environment, attributing ambiguous facts as frightening, always expecting something negative to happen to them and also expressing an inadequacy to effectively deal with a stressful situation.

An intergenerational association has also been studied extensively between conduct issues in the parents and its transmission to their children (43). While research evidences show a high genetic liability of transmission of conduct disorders in female children, for male children a bigger role of environmental factors in the intergenerational transmission has been observed. The probable causes for this have been identified as assortative mating among the generation of the parents for conduct related issues (44), a lifetime prevalence of other psychiatric condition in the parents, or the demographic factors of the family (45). Divorce among the parents (43) or strict and abusive parenting styles (46) are also observed to lead to conduct issues in the male children. An early onset of behavior is also related with neurodevelopmental issues in the child (47). Early onset of physical aggression and an overall high antisocial behavior were also observed in offsprings of mothers who were involved in delinquent behavior as juveniles. Factors responsible for the transmission were social adversities, sociodemographics (48), exposure of substance during perinatal period (43), or criminal involvement as in adult $(49,50)$.

Researches related intergenerational transmission of psychosis depict a sex-specific contribution on early onset of symptoms from parents to children. It has been observed that psychotic symptoms were more common among the female children when their fathers also had psychotic features and conversely, symptoms in the male child were linked to maternal possession of psychotic symptoms. A genetic transmission linked to the X-chromosome was observed to be the etiological factor for the transmission across generations (51). Research evidences on transmission of Schizophrenia spectrum disorder also point towards a major role of environmental factors, in addition to the genetic susceptibility. Low socio-economic conditions, a chronic course of parent's illness (52), pre- or perinatal maternal infections or other complications (53), physical maltreatment of emotional abuse of neglect during childhood (54), immigrating to a different place (55), cannabis use by mother during pregnancy, paternal age or season of birth are some of the environmental factors associated with intergenerational transmission of schizophrenia-like symptoms to the children (56).

Research evidences also point towards an increased risk of substance use in offsprings due to intergenerational transmission $(57,58)$. Provision of alcohol by parents for the adolescent $(59)$, alcohol use by parents, relational factors of the parent-child relationship (60), family conflict and positive attitudes of parents towards alcohol use (61) are some of the identified risk factors for alcohol use among offsprings of children with parents with a history of substance use. Transmission from parents to offsprings has also been reported in certain cases of chronic pain conditions (62). According to Higgins et. al. (63) children of parents with such pains report higher vulnerability to depressive and anxiety symptoms, poor social skills, increased complains of pains and lower levels of self-esteem than children of parents who do not report such chronic pains. A proposed model for this transmission mentions the causal factors as genetic, neurological, social learning of the pain related behavior, parenting style and health of the family as well as the environmental stressors (64).

Recently, researchers have aimed to attempt to ascertain the influence on the structural and functional brain structures due to intergenerational transmission and study that how are networks preserved over generations and it was observed that functional connectivity and grey matter volume is heritable and one of the factors responsible for the transmission (65).

\section{Models Explaining Intergeneration Transmis- sion}

Several theoretical frameworks have been proposed to explain the transmission of coping strategies and behavior that lead to enhanced susceptibility of mental health issues across the generations. Genetic and environmental factors are intertwined and play a key role in explaining intergenerational transmission of psychopathology (1). According to the social learning theory, parents may display maladaptive behavior, later imitated by the offspring through modeling (66). According to the Attachment theory of James Bowlby (67), the child's early experiences with their parent impact and shape the internal working models in all their relationships, as well as impact their future relationships and behavior. This theory too can explain intergenerational transmission as the child may adapt incongruent coping styles and behavior due to early interactions with their caregivers which may lead them towards mental health- related complications. Capsi et el. (68) spoke about 'intergenerational continuity' suggesting that the collective effect of an individual's environment which remains continuous across generations, results in the reinforcements of behavior and patterns of interaction encouraging and maintaining the behavioral patterns across the course 
of people's lives and next generations as well. Since individuals share the same economic, social, physical as well as cultural conditions, personality traits and behavior are also repetitive.

Goodman and Gotlib (69) gave the widely known Integrative model of transmitting risk from parents with depression to their offspring/s. The model talks about both environmental and biological factors and bidirectionality in the impact of transmission. This essentially means that while the behavior of the children is affected by the parents, the child's behavior also has a direct impact on that of the parents $(70,71)$. Therefore, the system of transmission of vulnerability relates to and overlaps with each other. The other risk factors mentioned are parental depression (72), both parents having depression (73), chronicity and high severity of parents' illness (74-76), difficult child temperament $(77,78)$, female gender of the child $(79,80)$ and social cognitive and intellectual deficits. There are also a number of non-specific factors like child abuse or poverty acting as risk factors for children to develop other psychiatric conditions too, in addition of depression (79) and therefore, the treatment plan should aim at tackling both specific and non-specific factors (81, 82).

The determinants of mechanisms for transmission in this model are heritability (83), innate dysfunctional neuroregulatory mechanism $(84,85)$, exposure to mother's maladaptive attitudes (86) and environmental stress (79) increasing the vulnerability of children and psychopathological consequences.

Kellerman (87) explained the transmission of trauma across generations through the psychodynamic model stating that the unconscious displacement of emotions that are transferred through the interpersonal relationships the child has with their parents. This leads to an unconscious absorption of repressed experiences of parents by the child and consequently, an undifferentiated development of self and others. He also spoke about the family systems model which explained that an ambiguous verbal and non-verbal communication patterns within the family lead to a secrecy' of unspoken experiences of the offspring and robustly creates troubles for the child in separation and differentiation from their parents' and their own experiences.

\section{Which Generation is the Worst Affected?}

The consequences of intergenerational transmission along with inequality badly influence adolescents and children towards mental illness. The adverse conditions of family may lead to the adolescents with decreased psychological resources to feel a sense of being trapped, anger, hopelessness, or frustration (88). Psychological issues of parents may cause rejection or hostility, or a decrease in parental involvement or commitment to children. These parental behavioral issues may push the child towards more complicated mental health issues (89). A research study by Wickrama et. al. (90) depicts that the children experiencing undesirable psychological issues during early years of life are exacerbated during transition to adulthood as the individuals may feel socially, emotionally and also financially unprepared to face the challenges and responsibilities to be born now (91). They may also be unable to acquire the adequate social and educational skills and receive less social support, further putting them in a place of disadvantage. All these may disrupt their healthy developmental processes and result into feeling 'trapped' in self-perpetuating cycle and experiencing adversity due to family conditions. So much so, it can also lead to a poor health status,and this distress and inequality may get accumulated over time in their life and get transmitted to the next generation (90).

\section{Prevention and Intervention of Intergenera- tional Transmission in Mental Health}

There has been a dearth of research in this context. Curran et. al. (92) believed that mental illness creates a cycle of trauma and adversity for the family. This may lead further to persistence of inequality experienced by the affected individuals, and ensures their suffering from generation to generation while stays in similar conditions and issues. Boursnell (93), therefore, talked about 'breaking the cycle' to a crucial step towards redemption. Sadly, the role of the family pertaining to such course of illness and its treatment is resisted in the mental health fields (94). Individuals with intergenerational trauma generally tend to approach mental health workers personally, seeking help for their trauma like symptoms but lacking the knowledge of association between their presently experienced symptoms and the trauma they or their families experienced in the past. They may also lack the ability to verbalize their emotions and thoughts (95). While mental health worker may be successful in helping these individuals, deal with the distress they experience, it would not help in complete remission as the underlying real cause/s for the condition are unknown or inadequately addressed (96). Thus, it is bound to make the intervention ineffective (13). Intervention strategies focusing on family are very important for prevention and intervention while addressing the mental illness in families and its intergenerational impact (97).

Prevention is considered as the most essential and preferred intervention strategy as it helps curbing the transfer of parental trauma and its effects onto the next generation (96). Primary prevention for transmission focuses on preventing the occurrence of the condition in normal population and this may be achieved by frequent screening of the population to identify individuals with trauma symptoms, training sessions for social workers or other individuals who may directly come in contact with parents and teaching them preventative parenting programs or social awareness programs that are provided at the community level for increasing awareness of the people. Secondary prevention is aimed at identifying the at-risk population and providing them with intervention techniques to limit the effects of it. And finally, tertiary prevention involves working closely with the affected population, for example, parents who are exposed to trauma and they and their children require interventions (98). The 'socio economic models of prevention' lay more focus on prevention at a community level as it is believed that individual family units are a part of a wider social dynamics. Therefore, a wider context must be considered while planning intervention strategies, and it may also include the clinical settings $(99,100)$.

Intervention strategies may be primarily aimed at working with the parent and aiming to resolve their trauma. The inability of the initial trauma survivor or the affected person interferes with normal healthy interactions and attachments with their offspring/s. This attachment plays a critical role of protecting or not protecting the offspring from experiencing the same or simi- 
lar distress (101). Cognitive behavior therapy (102), emotional regulation training, mindfulness, dialectical behavioral therapy (103), Eye Movement Desensitization and Reprocessing (EMDR) (104), Art therapy techniques (105), Yoga practices (106) are some of the techniques that can be used during individual psychotherapy with the affected parents. It is also essential to form a therapeutic relationship of trust and interpersonal security within the interaction (107). In addition to this, it is also crucial to work on the parent-child relationship and actively support them. The direct approach to work with this can be helping parents to acquire an appropriate response towards their child as well as the reflective abilities to reflect on their own experiences and their child's experiences too (108). And the indirect approach can be attempting to reduce the risk factors along with likely effects of parental mental illnesses, substance abuse, or their disorganized attachment styles and helping parents become more receptive and sensitive towards their offspring. This in turn would promote secure attachments between them (108).

Identification and promotion of protective factors among the families also emerged as a possible prevention strategy (61). Protective factors like parental monitoring (109), quality of parent-child relationship and parental support and involvement were some of the factors that predicted decreased alcohol use in offsprings of parents with history of substance use (61). In addition, reducing stigma about intergenerational transmission of mental health issues, encouraging parents to seek support, forming support groups and creating safe spaces for parents with adverse childhood experiences for seeking help, initiating intervention strategies for healthy parenting, adult skill building for parents, encouraging open communication and expression of love even amidst adversities can be some useful techniques to enhance the levels of resilience in affected individuals in helping develop and acquire necessary coping mechanisms. Besides, educating children and preparing them for the threat can also be a useful technique. As prevention may not always be possible, preparing the child for challenges they may face in future and develop mental illness due to transmission could also be highly helpful (110).

Research evidences also show that social support through positive buffering mechanisms may also act as a protective factor especially when parents are themselves caught up in their own psychological injuries. These may be social, cultural or familial resources to provide informational, instrumental or even emotional support to the family $(111,112)$. The social support helps in reducing stress of the parent (113) or creates more avenues for the child to form secure attachments from and feel a sense of safety and security for situations when the parents are indisposed (11). A research study by Hatch and others (114) on African American women and their preschool children observed that the mothers having high adverse childhood trauma and reported having a moderate to high familial social support did not witness increased externalizing behavior in their young children. Therefore, social support acted as a buffer and prevented intergenerational transmission of the mother's symptoms.

\section{Methodological Considerations}

However, there are some methodological limitations in the cited empirical evidences. Effects of gender differences in the offsprings have been largely neglected, neurobiological causes were also given less credit than what is due. Intergenerational transmission studies are usually conducted over multiple generations, to observe their behavior and cross sectional research designs are utilized in most studies. This reduces our ability to draw cause and affects inferences and also affects our understanding of the direction of the relationship. Therefore, longitudinal research design are relatively more suitable to study the said phenomena as it would have helped us observe the behavior and personality of individuals over long durations of time. There is also a dearth of research focusing on influence of cultural factors on transmission, like race, ethnicity etc.

Albeit, extensive researches have been conducted on intergenerational transmission of trauma, however, only few researches explored other specific psychiatric conditions and how they are transmitted across generations. Similarly, scanty researches have focused in identifying risk factors and interventions to be provided to individuals with specific disorder.

Extensive reviewing of literature points towards the very crucial role of genetic transmission of the vulnerability of psychiatric illness among children of affected parents. Future researches may hence be conducted to explore the realms of genetic screening and introduction of preventative interventions thereafter. We also observe a dearth of research in the field of intervention strategies aimed at working with the prevention as well as management of individuals or families affected by intergenerational transmission of mental health illnesses. Mostly the available researches have an individual approach for management and disregarded the importance of interventions involving working with the entire family. Therefore, future researches conducted in this field may have a huge impact to curb its adverse effects. More extensive researches on causal and risk factors can also increase early identification and intervention, and thus, help break the continuous cycle of intergenerational transmission. Future implications can be interventions promoting resilience in the children and their parents helping them to be better equipped to deal with adverse conditions (110).

Please find some salient researches along with their major findings and observed methodological flaws given below in a tabular form:

\section{Conclusion}

We therefore conclude that intergenerational transmission of mental health issues is, due to a dynamic interplay of both genetic and environmental components, impacting the offspring of the affected parents to some extent and adding to the vulnerability towards the subsequent development of several psychiatric issues. Having parents with psychiatric issues affect the child's home environment and interaction patterns with parents as they are not able to provide the child with an adequately nurturing environment, and thus translating into the faulty attachment styles the offspring develops. Other challenges owing to mental health issues of parents include socioeconomic difficulties and marginalization leading to stigmatization, decreased availability of social support, inability to acquire adequate academic competence and thus, the child may start replicating the maladaptive behaviors of their parents due to similar prevailing environmen- 
tal conditions. Hence the transmission of mental health issues continues across generations.

Early identification of the vulnerable population along with early interventions has been suggested as a useful method to curb the effects of intergenerational transmission. Working with the affected parents individually through psychotherapy and also understanding the role of the family and working to resolve their issues through familial interactions can be done. Working on the parent-child relationship, building resilience and promoting the protective factors like social support or early psychoeducation about illness have also been proposed to break the cycle of intergenerational transmission of inequality in psychological health.匹

\section{References}

1. Branje S, Geeraerts S, de Zeeuw EL, Oerlemans AM, Koopman-Verhoeff ME, Schulz S, Nelemans S, Meeus W, Hartman CA, Hillegers MHJ, Oldehinkel AJ, Boomsma DI. Intergenerational transmission: Theoretical and methodological issues and an introduction to four Dutch cohorts. Dev Cogn Neurosci 2020; 45:100835. DOI: https://doi.org/10.1016/i.den.2020.100835

2. Anderson LR. Adolescent mental health and behavioural problems, and intergenerational social mobility: A decomposition of health selection effects. Soc Sci Med 2018; 197:153-160. DOI: https://doi.org/10.1016/i.socscimed.2017.11.026

3. Currie J. Healthy, wealthy, and wise: Socioeconomic status, poor health in childhood, and human capital development. J Econ Lit 2009; 47(1):87-122. DOI: https://doi.org/10.3386/w13987

4. Johnston DW, Schurer S, Shields MA. Exploring the intergenerational persistence of mental health: Evidence from three generations. J Health Econ 2013; 32(6):1077-1089. DOI:

https://doi.org/10.1016/i.jhealeco.2013.09.001

5. van IJzendoorn MH, Bakermans-Kranenburg MJ, Sagi-Schwartz A. Are children of Holocaust survivors less well-adapted? A meta-analytic investigation of secondary traumatization. J Trauma Stress 2003; 16(5):459-469. DOI:

https://doi.org/10.1023/A:1025706427300

6. Dekel S, Mandl C, Solomon Z. Is the Holocaust implicated in posttraumatic growth in second-generation Holocaust survivors? A prospective study. J Trauma Stress 2013; 26(4):530-533. DOI: https://doi.org/10.1002/jts.21836

7. D'Onofrio BM, Slutske WS, Turkheimer E, Emery RE, Harden KP, Heath AC, Madden PA, Martin NG. Intergenerational transmission of childhood conduct problems: A Children of Twins Study. Arch Gen Psychiatry 2007; 64(7):820-829. DOI: https://doi.org/10.1001/archpsyc.64.7.820

8. de Girolamo G, Dagani J, Purcell R, Cocchi A, McGorry PD. Age of onset of mental disorders and use of mental health services: Needs, opportunities and obstacles. Epidemiol Psychiatr Sci 2012; 21(1):47-57. DOI: https://doi.org/10.1017/s2045796011000746

9. Yehuda R, Lehrner A. Intergenerational transmission

of trauma effects: Putative role of epigenetic mechanisms. World Psychiatry 2018 Oct;17(3):243-257. DOI: https://doi.org/10.1002/wps.20568

10. Kirmayer LJ, Gone JP, Moses J. Rethinking historical trauma. Transcult Psychiatry 2014; 51(3):299-319. DOI: https://doi.org/10.1177/1363461514536358

11. Hesse E, Main M. Disorganized infant, child, and adult attachment: Collapse in behavioral and attentional strategies. J Am Psychoanal Assoc 2000; 48(4):1097-1127; discussion 1175-1187. DOI: https://doi.org/10.1177/00030651000480041101

12. Mazor A, Tal I. Intergenerational transmission: The individuation process and the capacity for intimacy of adult children of holocaust survivors. Contemp Fam Ther 1996; 18:95-113. DOI: https://doi.org/10.1007/BF02196853

13. O'Neill L, Fraser T, Kitchenham A, McDonald V. Hidden burdens: A review of intergenerational, historical and complex trauma, implications for indigenous families. J Child Adolesc Trauma 2016; 11(2):173-186. DOI: https://doi.org/10.1007/s40653-016-0117-9

14. Schore AN. Dysregulation of the right brain: A fundamental mechanism of traumatic attachment and the psychopathogenesis of posttraumatic stress disorder. Aust N Z J Psychiatry 2002; 36(1):9-30. DOI: https://doi.org/10.1046/j.1440-1614.2002.00996.x

15. Fenerci RLB, Chu AT, DePrince AP. Intergenerational transmission of trauma-related distress: Maternal betrayal trauma, parenting attitudes, and behaviors. J Aggress Maltreat Trauma 2016; 25:4:382-399. DOI: https://doi.org/10.1080/10926771.2015.1129655

16. Chu A, Deprince AP. Development of dissociation: examining the relationship between parenting, maternal trauma and child dissociation. J Trauma Dissociation 2006; 7(4):75-89. DOI: https://doi.org/10.1300/J229v07n04 05

17. Briere J. New frontiers in trauma treatment. Conference proceedings. Richmond: Jack Hirose \& Associates Inc., 2005.

18. Bridgett DJ, Burt NM, Edwards ES, Deater-Deckard K Intergenerational transmission of self-regulation: A multidisciplinary review and integrative conceptual framework. Psychol Bull 2015; 141(3):602-654. DOI: https://doi.org/10.1037/a0038662 
19. Boulton J. History branded on the mind: Trans-generational trauma in aboriginal Australia. Health History 2018; 20(2):100-105.

20. Gone JP, Kirmayer LJ. Advancing Indigenous Mental Health Research: Ethical, conceptual and methodological challenges. Transcult Psychiatry 2020; 57(2):235-249. DOI: https://doi.org/10.1177/1363461520923151

21. Griffiths K, Coleman C, Lee V, Madden R. How colonisation determines social justice and indigenous health - A review of the literature. J Pop Res 2016; 33(1):9-30. DOI: https://doi.org/10.1007/s12546-016-9164-1

22. Hoosain S. Decolonising social work research with families experiencing intergenerational trauma. Southern Afr J Soc Work Soc Develop 2018; 30(1):1-18. DOI: https://doi.org/10.25159/2415-5829/2471

23. Davoine, F. and J. Gaudilliere (2004) History beyond Trauma. New York: Other Press. Revised Ed., March 17, 2004. ISBN-13: 9781590511114.

24. Eisenbruch M. From post-traumatic stress disorder to cultural bereavement: diagnosis of Southeast Asian refugees. Soc Sci Med 1991; 33(6):673-680. DOI: https://doi.org/10.1016/0277-9536(91)90021-4

25. Herman JL. Trauma and Recovery: The Aftermath of Violence - From Domestic Abuse to Political Terror New York: Harper Collins; London: Basic Books. ISBN13: 9780465087303. 1992.

26. Insana SP, Foley KP, Montgomery-Downs HE, Kolko DJ, McNeil CB. Children exposed to intimate partner violence demonstrate disturbed sleep and impaired functional outcomes. Psychol Trauma Theory Res Pract Policy 2014; 6(3):290-298. https://doi.org/10.1037/a0033108

27. Brennan PA, Hammen C, Katz AR, Le Brocque RM. Maternal depression, paternal psychopathology, and adolescent diagnostic outcomes. J Consult Clin Psychol 2002; 70(5):1075-1085. DOI: https://doi.org/10.1037//0022-006x.70.5.1075

28. Kim HK, Capaldi DM, Pears KC, Kerr DC, Owen LD Intergenerational transmission of internalising and externalising behaviours across three generations: Gender-specific pathways. Crim Behav Ment Health 2009; 19(2):125-141. DOI: https://doi.org/10.1002/cbm.708

29. Hammen $\mathrm{C}$, Shih JH, Brennan PA. Intergenerational transmission of depression: Test of an interpersonal stress model in a community sample. $\mathrm{J}$ Consult Clin Psychol 2004; 72(3):511-522. DOI: https://doi.org/10.1037/0022-006X.72.3.511

30. Jaffee SR, Sligo JL, McAnally HM, Bolton AE, Baxter JM, Hancox RJ. Early-onset and recurrent depression in parents increases risk of intergenerational transmission to adolescent offspring. J Child Psychol Psychiatry 2021; 62(8):979-988. DOI: https://doi.org/10.1111/icpp.13356

31. O'Reilly LM, Kuja-Halkola R, Rickert ME, Class QA, Larsson H, Lichtenstein P, D'Onofrio BM. The intergenerational transmission of suicidal behavior: An offspring of siblings study. Transl Psychiatry 2020; 10(1):173. DOI: https://doi.org/10.1038/s41398-020-0850-6

32. Brent DA, Mann JJ. Family genetic studies, suicide, and suicidal behavior. Am J Med Genet C Semin Med Genet 2005; 133C(1):13-24. DOI: https://doi.org/10.1002/ajmg.c.30042

33. Brent DA, Melhem N. Familial transmission of suicidal behavior. Psychiatr Clin North Am 2008; 31(2):157-177. DOI: https://doi.org/10.1016/j.psc.2008.02.001

34. Baller RD, Richardson KK. Social integration, imitation, and the geographic patterning of suicide. Am Sociol Rev 2002; 67(6):873-888. DOI: https://doi.org/10.2307/3088974

35. Botsis AJ, Plutchik R, Kotler M, van Praag HM. Parental loss and family violence as correlates of suicide and violence risk. Suicide Life Threat Behav 1995; 25(2):253-260.

36. Janet Kuramoto S, Brent DA, Wilcox HC. The impact of parental suicide on child and adolescent offspring. Suicide Life Threat Behav 2009; 39(2):137-151. DOI: https://doi.org/10.1521/suli.2009.39.2.137

37. Brent DA, Baugher M, Bridge J, Chen T, Chiappetta L. Age- and sex-related risk factors for adolescent suicide. J Am Acad Child Adolesc Psychiatry 1999; 38(12):1497-1505. DOI: https://doi.org/10.1097/00004583-199912000-00010

38. Brent DA, Perper JA, Moritz G, Liotus L, Schweers J, Balach L, Roth C. Familial risk factors for adolescent suicide: A case-control study. Acta Psychiatr Scand 1994; 89(1):52-58. DOI: https://doi.org/10.1111/j.1600-0447.1994.tb01485.x

39. Nock MK. Future directions for the study of suicide and self-injury. J Clin Child Adolesc Psychol 2012; 41(2):255-259. DOI: https://doi.org/10.1080/15374416.2012.652001

40. Mackenzie R. Intergenerational transmission of anxiety: The influence of parental anxiety on child-related information processing biases. The University of Manchester (United Kingdom). 2011.

41. Creswell C., Cooper P, Murray L. Intergenerational transmission of anxious information processing biases. In J. A. Hadwin, \& A. P. Field (Eds.).33 Information processing biases and anxiety: A developmental perspective (pp. 279-296). Chichester, UK: Wiley-Blackwell. 2010.

42. Daleiden EL, Vasey MW. An information-processing perspective on childhood anxiety. Clin Psychol Rev 1997; 17(4):407-429. DOI: https://doi.org/10.1016/s0272-7358(97)00010-x

43. D'Onofrio BM, Turkheimer E, Emery RE, Maes $\mathrm{HH}$, Silberg J, Eaves LJ. A Children of Twins Study of parental divorce and offspring psychopathology. J Child Psychol Psychiatry 2007; 48(7):667-675. DOI: https://doi.org/10.1111/j.1469-7610.2007.01741.x

44. Krueger RF, Moffitt TE, Caspi A, Bleske A, Silva PA. Assortative mating for antisocial behavior: Developmental and methodological implications. Behav Genet 1998; 28(3):173-186. DOI: https://doi.org/10.1023/a:1021419013124

45. Lahey BB, Miller TL, Gordon RA, Riley AW. Developmental epidemiology of the disruptive behavior 
disorders. In Handbook of disruptive behavior disorders (pp. 23-48). Springer, Boston, MA. 1999.

46. D'Onofrio BM, Turkheimer E, Emery RE, Slutske WS, Heath AC, Madden PA, Martin NG. A genetically informed study of the processes underlying the association between parental marital instability and offspring adjustment. Dev Psychol 2006; 42(3):486-499. DOI: https://doi.org/10.1037/0012-1649.42.3.486

47. Moffitt TE. Adolescence-limited and life-course-persistent antisocial behavior: A developmental taxonomy. Psychol Rev 1993; 100(4):674-701.

48. Moffitt TE, Caspi A, Rutter M, Silva PA. Sex differences in antisocial behaviour: Conduct disorder, delinquency, and violence in the Dunedin Longitudinal Study. Cambridge University Press. 2001. DOI: https://doi.org/10.1017/CBO9780511490057

49. Tzoumakis S, Lussier P, Corrado R. Female juvenile delinquency, motherhood, and the intergenerational transmission of aggression and antisocial behavior. Behav Sci Law 2012; 30(2):211-37. DOI: https://doi.org/10.1002/bsl.2010

50. Tracy PE, Kempf Leonard K. Continuity and discontinuity in criminal. New York: Plenum Press. ISBN: 9781475798449. 1996.

51. Aylott A, Zwicker A, MacKenzie LE, Cumby J, Propper L, Abidi S, Bagnell A, Fisher HL, Pavlova B, Alda M, Uher R. Like father like daughter: Sex-specific parent-of-origin effects in the transmission of liability for psychotic symptoms to offspring. $J$ Dev Orig Health Dis 2019; 10(1):100-107. DOI: https://doi.org/10.1017/S2040174418000612

52. Sameroff A, Seifer R, Zax M, Barocas R. Early indicators of developmental risk: Rochester Longitudinal Study. Schizophr Bull 1987; 13(3):383-394. DOI: https://doi.org/10.1093/schbul/13.3.383

53. Brown AS, Derkits EJ. Prenatal infection and schizophrenia: A review of epidemiologic and translational studies. Am J Psychiatry 2010; 167(3):261-280. DOI: https://doi.org/10.1176/appi.ajp.2009.09030361

54. Varese F, Smeets F, Drukker M, Lieverse R, Lataster T, Viechtbauer W, Read J, van Os J, Bentall RP. Childhood adversities increase the risk of psychosis: A meta-analysis of patient-control, prospective- and cross-sectional cohort studies. Schizophr Bull 2012; 38(4):661-671. DOI: https://doi.org/10.1093/schbul/sbs050

55. Cantor-Graae E, Selten JP. Schizophrenia and migration: A meta-analysis and review. Am J Psychiatry 2005; 162(1):12-24. DOI: https://doi.org/10.1176/appi.ajp.162.1.12

56. Padmanabhan JL, Shah JL, Tandon N, Keshavan MS. The "polyenviromic risk score": Aggregating environmental risk factors predicts conversion to psychosis in familial high-risk subjects. Schizophr Res 2017; 181:17-22. DOI:

https://doi.org/10.1016/i.schres.2016.10.014

57. Kerr DCR, Capaldi DM. Introduction to the special section on the intergenerational transmission of risk for substance use. Psychol Addict Behav 2020; 34(8):811-817. DOI: https://doi.org/10.1037/adb0000652
58. Neppl TK, Diggs ON, Cleveland MJ. The intergenerational transmission of harsh parenting, substance use, and emotional distress: Impact on the third-generation child. Psychol Addict Behav 2020; 34(8):852-863. DOI: https://doi.org/10.1037/adb0000551

59. Brook JS, Brook DW, Gordon AS, Whiteman M, Cohen $P$. The psychosocial etiology of adolescent drug use: A family interactional approach. Genet Soc Gen Psychol Monogr 1990; 116(2):111-267.

60. Andrews JA, Hops H, Duncan SC. Adolescent modeling of parent substance use: The moderating effect of the relationship with the parent. J Fam Psychol 1997; 11(3):259-270. DOI: https://doi.org/https://doi.org/10.1037/0893-3200.11.3 .259

61. Yap MBH, Cheong TWK, Zaravinos-Tsakos F, Lubman DI, Jorm AF. Modifiable parenting factors associated with adolescent alcohol misuse: A systematic review and meta-analysis of longitudinal studies. Addiction 2017; 112(7):1142-1162. DOI: https://doi.org/10.1111/add.13785

62. Patton M, Stokoe M, Forbes C, Nwaroh C, Noel M, Reynolds K, Schulte F. The intergenerational transmission of chronic pain from parents to survivors of childhood cancer. Children (Basel) 2020; 7(11):246. DOI: https://doi.org/10.3390/children7110246

63. Higgins KS, Birnie KA, Chambers CT, Wilson AC Caes L, Clark AJ, Lynch M, Stinson J, Campbell-Yeo M. Offspring of parents with chronic pain: A systematic review and meta-analysis of pain, health, psychological, and family outcomes. Pain 2015 ; 156(11):2256-2266. DOI: https://doi.org/10.1097/i.pain.0000000000000293

64. Stone AL, Wilson AC. Transmission of risk from parents with chronic pain to offspring: An integrative conceptual model. Pain 2016; 157(12):2628-2639. DOI: https://doi.org/10.1097/j.pain.0000000000000637

65. Takagi Y, Okada N, Ando S, Yahata N, Morita K, Koshiyama D, Kawakami S, Sawada K, Koike S, Endo K, Yamasaki S, Nishida A, Kasai K, Tanaka SC. Intergenerational transmission of the patterns of functional and structural brain networks. iScience 2021; 24(7):102708. DOI: https://doi.org/10.1016/j.isci.2021.102708

66. Patterson GR. Continuities--a search for causal mechanisms: Comment on the special section. Dev Psychol 1998; 34(6):1263-1268. DOI: https://doi.org/10.1037//0012-1649.34.6.1263

67. Bowlby J. A Secure Base. Clinical Applications of Attachment Theory. Routledge, London. Psychology Press. 1988. ISBN: 9780415006408.

68. Caspi A, Bem DJ, Elder GH Jr. Continuities and consequences of interactional styles across the life course. J Pers 1989; 57(2):375-406. DOI: https://doi.org/10.1111/j.1467-6494.1989.tb00487.x

69. Goodman SH, Gotlib IH. Children of depressed parents: Mechanisms of risk and implications for treatment. Washington, DC. 2002. ISBN: 9781557988751.

70. Forbes EE, Shaw DS, Silk JS, Feng X, Cohn JF, Fox 
NA, Kovacs M. Children's affect expression and frontal EEG asymmetry: transactional associations with mothers' depressive symptoms. J Abnorm Child Psychol 2008; 36(2):207-221. DOI: https://doi.org/10.1007/s10802-007-9171-y

71. Gross HE, Shaw DS, Moilanen KL. Reciprocal associations between boys' externalizing problems and mothers' depressive symptoms. J Abnorm Child Psychol 2008; 36(5):693-709. DOI: https://doi.org/10.1007/s10802-008-9224-x

72. Wilson S, Durbin CE. Effects of paternal depression on fathers' parenting behaviors: A meta-analytic review. Clin Psychol Rev 2010; 30(2):167-180. DOI: https://doi.org/10.1016/j.cpr.2009.10.007

73. Kane P, Garber J. Parental depression and child externalizing and internalizing symptoms: Unique effects of fathers' symptoms and perceived conflict as a mediator. J Child Fam Stud 2009; 18(4):465-472. DOI: https://doi.org/10.1007/s10826-008-9250-x

74. Brennan PA, Hammen C, Andersen MJ, Bor W, Najman JM, Williams GM. Chronicity, severity, and timing of maternal depressive symptoms: Relationships with child outcomes at age 5. Dev Psychol 2000; 36(6):759-766. DOI: https://doi.org/10.1037//0012-1649.36.6.759

75. Brennan PA, Le Brocque R, Hammen C. Maternal depression, parent-child relationships, and resilient outcomes in adolescence. J Am Acad Child Adolesc Psychiatry 2003; 42(12):1469-1477. DOI: https://doi.org/10.1097/00004583-200312000-00014

76. Campbell SB, Morgan-Lopez AA, Cox MJ, McLoyd VC. A latent class analysis of maternal depressive symptoms over 12 years and offspring adjustment in adolescence. J Abnorm Psychol 2009; 118(3):479-493. DOI: https://doi.org/10.1037/a0015923

77. Bruder-Costello B, Warner V, Talati A, Nomura Y, Bruder G, Weissman M. Temperament among offspring at high and low risk for depression. Psychiatry Res 2007; 153(2):145-151. DOI: https://doi.org/10.1016/j.psychres.2007.02.013

78. Chazan-Cohen R, Ayoub C, Pan BA, Roggman L, Raikes H, Mckelvey L, Whiteside-Mansell L, Hart A. It takes time: Impacts of Early Head Start that lead to reductions in maternal depression two years later. Infant Ment Health J 2007; 28(2):151-170. DOI: https://doi.org/10.1002/imhj.20127

79. England MJ, Sim LJ, National Research Council. Treatment of Depression in Parents. In Depression in parents, parenting, and children: Opportunities to improve identification, treatment, and prevention. National Academies Press (US). 2009.

80. Reeb BT, Conger KJ, Wu EY. Paternal depressive symptoms and adolescent functioning: The moderating effect of gender and father hostility. Fathering 2010; 8(1):131-142. DOI: https://doi.org/10.3149/fth.0801.131

81. Beardslee WR, Versage EM, Gladstone TR. Children of affectively ill parents: A review of the past 10 years. J Am Acad Child Adolesc Psychiatry 1998.

37(11):1134-1141. DOI: https://doi.org/10.1097/00004583-199811000-00012
82. Committee NRCaloMP. Preventing Mental, Emotional, and Behavioral Disorders among Young People: Progress and Possibilities. Washington, DC: National Academies Press. 2009.

83. Bagot RC, Meaney MJ. Epigenetics and the biological basis of gene $x$ environment interactions. J Am Acad Child Adolesc Psychiatry. 2010; 49(8):752-771. DOI: https://doi.org/10.1016/i.jaac.2010.06.001

84. Bruder GE, Tenke CE, Warner V, Weissman MM. Grandchildren at high and low risk for depression differ in EEG measures of regional brain asymmetry. Biol Psychiatry 2007; 62(11):1317-1323. DOI: https://doi.org/10.1016/j.biopsych.2006.12.006

85. Gotlib IH, Hamilton JP, Cooney RE, Singh MK, Henry ML, Joormann J. Neural processing of reward and loss in girls at risk for major depression. Arch Gen Psychiatry 2010; 67(4):380-387. DOI: https://doi.org/10.1001/archgenpsychiatry.2010.13

86. Lovejoy MC, Graczyk PA, O'Hare E, Neuman G. Maternal depression and parenting behavior: A meta-analytic review. Clin Psychol Rev 2000; 20(5):561-592. DOI: https://doi.org/10.1016/s0272-7358(98)00100-7

87. Kellermann NP. Transmission of Holocaust trauma--An integrative view. Psychiatry 2001; 64(3):256-267. DOI: https://doi.org/10.1521/psyc.64.3.256.18464

88. Brown GW. Social roles, context and evolution in the origins of depression. J Health Soc Behav 2002; 43(3):255-276.

89. Conger RD, Ge X, Elder GH Jr, Lorenz FO, Simons $\mathrm{RL}$. Economic stress, coercive family process, and developmental problems of adolescents. Child Dev 1994; 65(2 Spec No):541-561.

90. Wickrama KA, Conger RD, Abraham WT. Early adversity and later health: The intergenerational transmission of adversity through mental disorder and physical illness. J Gerontol B Psychol Sci Soc Sci 2005; 60 Spec No 2:125-129. DOI: https://doi.org/10.1093/geronb/60.special issue 2.s1 $\underline{25}$

91. Wickrama KA, Conger RD, Wallace LE, Elder GH Jr. Linking early social risks to impaired physical health during the transition to adulthood. J Health Soc Behav 2003; 44(1):61-74.

92. Curran E, Adamson G, Stringer M, Rosato M, Leavey G. Severity of mental illness as a result of multiple childhood adversities: US National Epidemiologic Survey. Soc Psychiatry Psychiatr Epidemiol 2016; 51(5):647-657. DOI: https://doi.org/10.1007/s00127-016-1198-3

93. Boursnell M. Parents with mental illness: The cycle of intergenerational mental illness. Children Australia 2011; 36(1):26-35. doi: https://doi.org/10.1375/jcas.36.1.26

94. Wyder M, Bland R. The recovery framework as a way of understanding families' responses to mental illness: Balancing different needs and recovery journeys. Austral Soc Work 2014; 67(2):179-196. DOI: https://doi.org/10.1080/0312407X.2013.875580

95. Edwards VJ, Holden GW, Felitti VJ, Anda RF. Rela- 
tionship between multiple forms of childhood maltreatment and adult mental health in community respondents: Results from the adverse childhood experiences study. Am J Psychiatry 2003;

160(8):1453-1460. DOI:

https://doi.org/10.1176/appi.ajp.160.8.1453

96. Isobel S, Goodyear M, Furness T, Foster K. Preventing intergenerational trauma transmission: A critical interpretive synthesis. J Clin Nurs 2019; 28(7-8):1100-1113. DOI: https://doi.org/10.1111/jocn.14735

97. Foster K, Maybery D, Reupert A, Gladstone B, Grant A, Ruud T, Falkov A, Kowalenk N. (2016). Family-focused practice in mental health care: An integrative review. Child Youth Serv 2016; 37(2):129-155. DOI: https://doi.org/10.1080/0145935X.2016.1104048

98. Magruder KM, Kassam-Adams N, Thoresen S, Olff M. Prevention and public health approaches to trauma and traumatic stress: A rationale and a call to action. Eur J Psychotraumatol 2016; 7:29715. DOI: https://doi.org/10.3402/ejpt.v7.29715

99. Cyr C, Michel G, Dumais M. Child maltreatment as a global phenomenon: from trauma to prevention. Int $\mathrm{J}$ Psychol 2013; 48(2):141-148. DOI: https://doi.org/10.1080/00207594.2012.705435

100. Isobel S, Goodyear M, Foster K. Psychological trauma in the context of familial relationships: A concept analysis. Trauma Violence Abuse 2019; 20(4):549-559. DOI: https://doi.org/10.1177/1524838017726424

101.Schwerdtfeger KL, Goff BS. Intergenerational transmission of trauma: Exploring mother-infant prenatal attachment. J Trauma Stress 2007; 20(1):39-51. DOI: https://doi.org/10.1002/its.20179

102. Gillies D, Taylor F, Gray C, O’Brien L, D'Abrew N. Psychological therapies for the treatment of post-traumatic stress disorder in children and adolescents (Review). Evid Based Child Health 2013; 8(3):1004-1116. DOI: https://doi.org/10.1002/ebch.1916

103. Siegel JP. Breaking the links in intergenerational violence: An emotional regulation perspective. Fam Process 2013; 52(2):163-178. DOI: https://doi.org/10.1111/famp.12023

104.Shapiro F, Maxfield L. Eye Movement Desensitization and Reprocessing (EMDR): Information processing in the treatment of trauma. J Clin Psychol 2002; 58(8):933-946. DOI: https://doi.org/10.1002/jclp.10068

105. Chong CYJ. Why art psychotherapy? Through the lens of interpersonal neurobiology: The distinctive role of art psychotherapy intervention for clients with early relational trauma. Int J Art Ther 2015; 20(3):118-126.

106.van der Kolk BA, Stone L, West J, Rhodes A, Emerson D, Suvak M, Spinazzola J. Yoga as an adjunctive treatment for posttraumatic stress disorder: A randomized controlled trial. J Clin Psychiatry 2014; 75(6):e559-65. DOI:

https://doi.org/10.4088/JCP.13m08561

107.Seager M. The concept of 'psychological safety' - a psychoanalytically-informed contribution towards 'safe, sound \& supportive' mental health services. Psychoanal Psychother 2006; 20(4):266-280. DOI: https://doi.org/10.1080/02668730601020291

108. Letourneau N, Tryphonopoulos P, Giesbrecht G, Dennis CL, Bhogal S, Watson B. Narrative and meta-analytic review of interventions aiming to improve maternal-child attachment security. Infant Ment Health J 2015; 36(4):366-387. DOI: https://doi.org/10.1002/imhj.21525

109. Stattin H, Kerr M. Parental monitoring: A reinterpretation. Child Dev 2000; 71(4):1072-1085. DOI: https://doi.org/10.1111/1467-8624.00210

110.Woods-Jaeger BA, Cho B, Sexton CC, Slagel L, Goggin K. Promoting resilience: Breaking the intergenerational cycle of adverse childhood experiences. Health Educ Behav 2018; 45(5):772-780. DOI: https://doi.org/10.1177/1090198117752785

111. Aisenberg E, Ell K. Contextualizing community violence and its effects: An ecological model of parent-child interdependent coping. J Interpers Violence 2005; 20(7):855-871. DOI: https://doi.org/10.1177/0886260505276833

112. Andresen PA, Telleen SL. The relationship between social support and maternal behaviors and attitudes: A meta-analytic review. Am J Community Psychol 1992; 20(6):753-774.

113. Racine N, Plamondon A, Hentges R, Tough S, Madigan S. Dynamic and bidirectional associations between maternal stress, anxiety, and social support: The critical role of partner and family support. J Affect Disord 2019; 252:19-24. DOI: https://doi.org/10.1016/i.jad.2019.03.083

114. Hatch V, Swerbenski H, Gray SAO. Family social support buffers the intergenerational association of maternal adverse childhood experiences and preschoolers' externalizing behavior. Am J Orthopsychiatry 2020; 90(4):489-501. DOI: https://doi.org/10.1037/ort0000451

Received: July 22, 2021 | Revised: July 25, $2021 \quad$ Accepted: August 05, 2021 